\title{
Simulation Study of Natural Ventilation in Traditional and Contemporary Javanese Houses in Yogyakarta
}

\author{
Tri Yuni Iswati1 \\ 1 Architecture Department/Engeneering Faculty, Sebelas Maret University, Indonesia \\ yuni_iswati@yahoo.com
}

\begin{abstract}
Background research is to see how many contemporary houses that much different from the Javanese house, contemporary house is usually attached to each other neighbor's house, do not have a yard, use half a stone wall, while the Javanese house has a large yard, far enough distance between the house and use a single wall stone. Objectives of this paper is to show natural differences in ventilation resulting from the use of materials, and types of homes are these different settings. Methodology used is to use CFD simulations to see how the difference and temperature difference. Using the measurement data base BMKG with winds measured at a height of $10 \mathrm{~m}$ on the hottest and coldest months. Outcomes are the temperature and wind speed in Java proved to be more comfortable home. Summary The results proved that the traditional Javanese house more comfortable because it uses the hinge side windows, that make it easier for air to flow than the type of window (upper hinge) and one brick wall material further inhibit heat conduction than half brick wall.
\end{abstract}

Keywords: natural ventilation, traditional house, contemporary house

\section{Introduction}

In this paper will discuss the comparison of natural ventilation (air movement) on a traditional Javanese house that is in the town and at contemporary house. According to Fanger (1982) there are 6 factors that affect thermal comfort, 4 external and 2 of the human itself. Four of these factors are temperature $\left({ }^{\circ} \mathrm{C}\right)$, the average radiation temperature $\left({ }^{\circ} \mathrm{C}\right)$, humidity $(\%)$, wind speed $(\mathrm{m} / \mathrm{s})$, and two other factor is the activity $(\mathrm{W} / \mathrm{m} 2)$ and clothing (m2 deg C/W). This paper will discuss a particular wind speed will affect the temperature in the room. In this paper will discuss the differences in natural ventilation that occurs in traditional houses Kotagede and contemporary houses in Yogyakarta. This refers to the materials used in both cases.

\section{Materials and Method}

\subsection{Literature Review}

According to Koenigsberger et al, thermal comfort is at $30-65 \%$ humidity, temperature DBT (21-30) under $100^{\circ} \mathrm{C}$ radiation in $\mathrm{W} / \mathrm{m} 2$ for men to wear was in temperate. Each point on the diagramme shows dry bulb temperature (DBT), wet bulb temperature (WBT), (RH relative Humidity), (AH absolute humidity), and vapor pressure. Difference in dry bulb and wet bulb will show humidity air at the time in question. If the temperature of both the ball as it means the relative humidity of $100 \%$. 


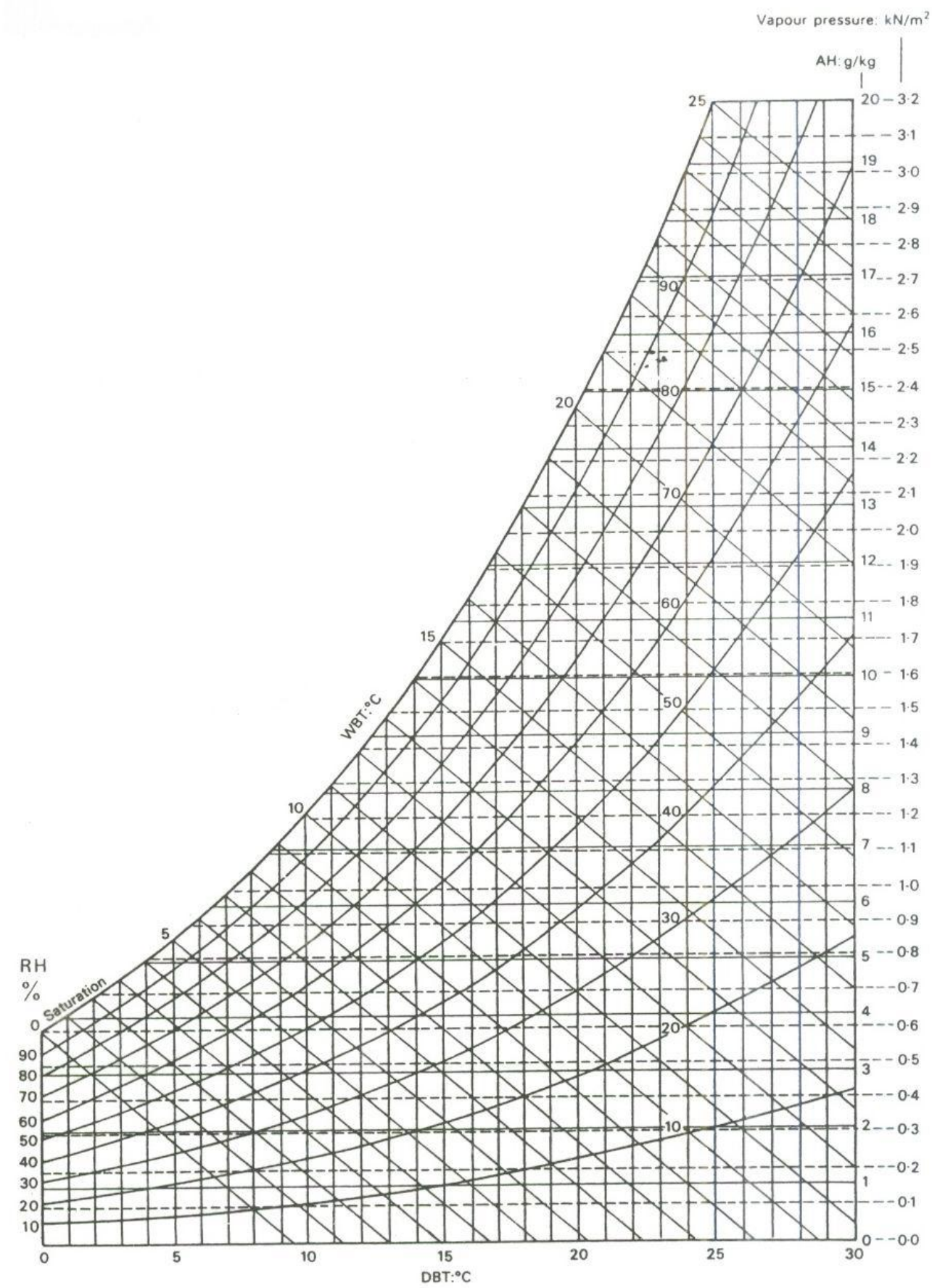

Figure 1. Psychrometric Chart

(Source: Koeningsberger, 1978)

According Satwiko (2008) for thermal comfort humid tropics is at a temperature of $24^{\circ} \mathrm{C}<\mathrm{T}<26^{\circ} \mathrm{C}, 40 \%<\mathrm{RH}<60 \%, 0.6<\mathrm{V}<1.5 \mathrm{~m} / \mathrm{s}$, a layer of lightweight clothing, activities relaxed calm. 


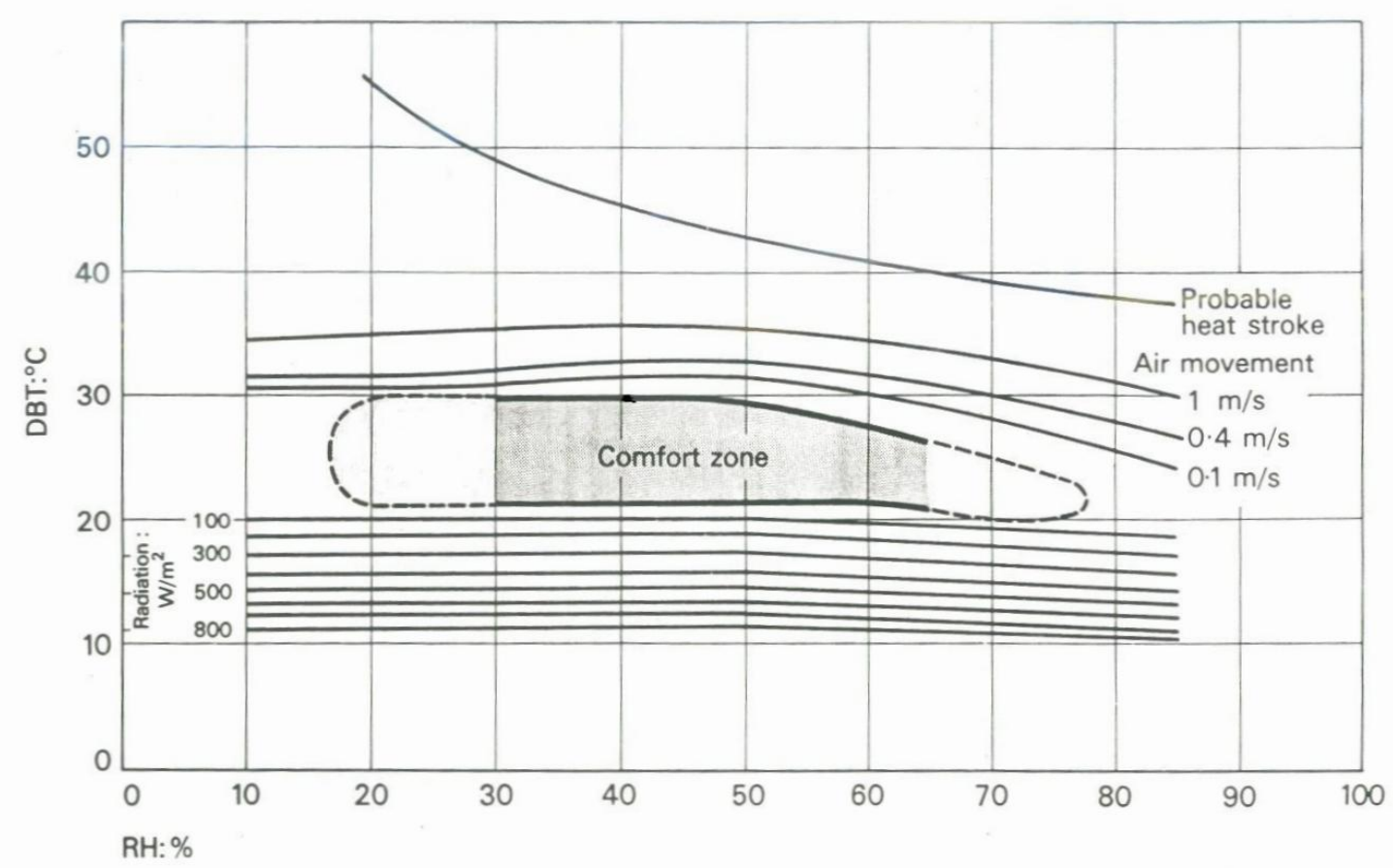

Figure 2. Bioclimatic Chart

(Source: Satwiko, 2008)

Thick walls have a greater time lag. The wall thickness is suitable for humid tropical climate. Because it can mainta in the coolness of the room on a hot day. At night is not quite effective because the temperature difference between day and night not too far away. So at night when the temperature of the heat off the wall in the room is still quite high. For the tropical climate is very suitable supported with high ceilings, tile-roofed. In addition the use of multiple windows. That window glass inside and outside blinds are very suitable for humid tropical climate. At Kotagede's house material used is wood windows, wooden bars on the inside, one brick wall, clay roof tiles, floor tiles, without a ceiling with a large yard.

\subsection{Methodology}

The methodology used in this study is the simulation of a simulation study using CFD (Computational Fluids Dynamics) with data from measurements made on the assumption BMKG (Meteorology Climatology Geophysics Board) height of $10 \mathrm{~m}$ from ground level. Objects being compared are the traditional houses in the area Kotagede and contemporary homes in residential areas Gowok, Sleman, Yogyakarta. Extents compared to approximately $150 \mathrm{~m} 2$. Assuming the same direction toward the building. Building materials for the aspect that distinguishes the measurement. Simulation by taking data at the hottest temperature (October) and coldest (July).

\section{Result and Discussions}


In Traditional house on the coldest temperature of more $298.5{ }^{\circ} \mathrm{K}=25.35{ }^{\circ} \mathrm{C}$ some were $299.5^{\circ} \mathrm{K}=26.35{ }^{\circ} \mathrm{C}$ (Fig.4). In Contemporary house on the coldest temperature of all the same inside and outside buildings $299.5{ }^{\circ} \mathrm{K}=26.35{ }^{\circ} \mathrm{C}$ (Fig.3). Contemporary on the hottest temperature of more $299.8^{\circ} \mathrm{K}=26.65^{\circ} \mathrm{C}$ in some parts of $300.5^{\circ} \mathrm{K}=27.35{ }^{\circ} \mathrm{C}$ (Fig.3). Traditional hottest temperature more $299.8^{\circ} \mathrm{K}=26.65{ }^{\circ} \mathrm{C}$ in some parts of $300.5^{\circ} \mathrm{K}=27.35$ ${ }^{\circ} \mathrm{C}$ (Fig.6).

So at the hottest temperature in both houses contemporary and traditional homes do not have a significant difference because both dominant temperature is $26.65{ }^{\circ} \mathrm{C}$ and some parts of $27.35{ }^{\circ} \mathrm{C}$. but the difference is the coldest month temperature at which the temperature of contemporary home inside and outside the same room is $26.35{ }^{\circ} \mathrm{C}$, while the traditional home has a temperature of dominant sections $25.35^{\circ} \mathrm{C}$ and the other part is $26.35^{\circ} \mathrm{C}$.

Note: Green $300.5^{\circ} \mathrm{K}=27.35^{\circ} \mathrm{C}$, Young Greens $299.8^{\circ} \mathrm{K}=26.65^{\circ} \mathrm{C}$

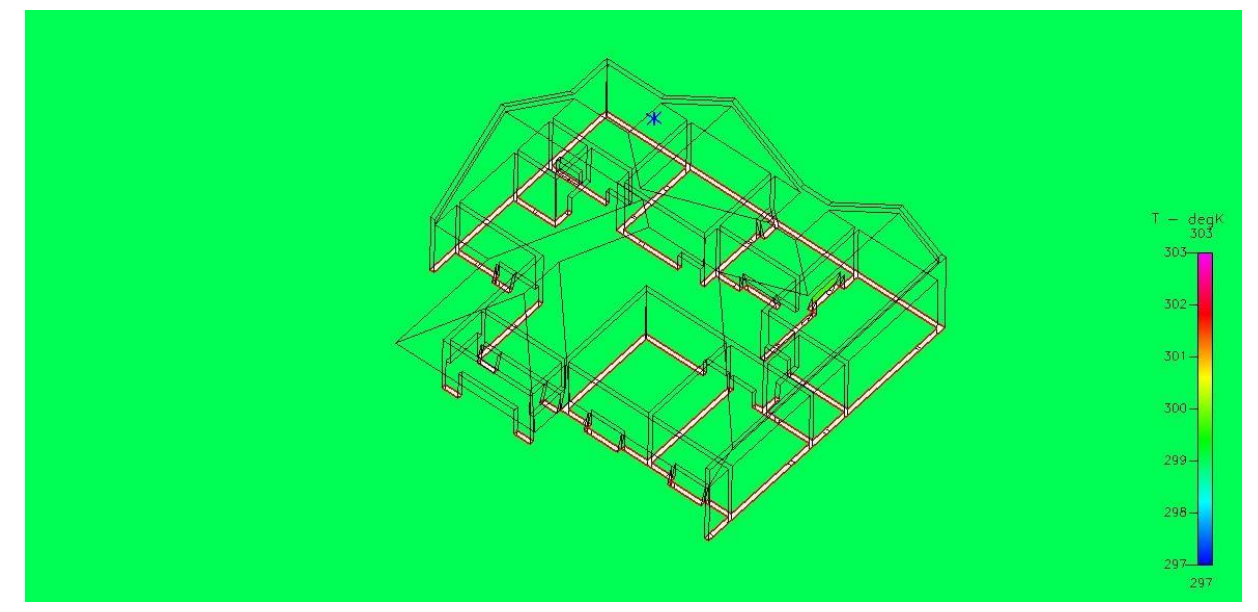

Figure 3. simulation of temperature on the contemporary home on the coldest month (Source: Author, 2011)

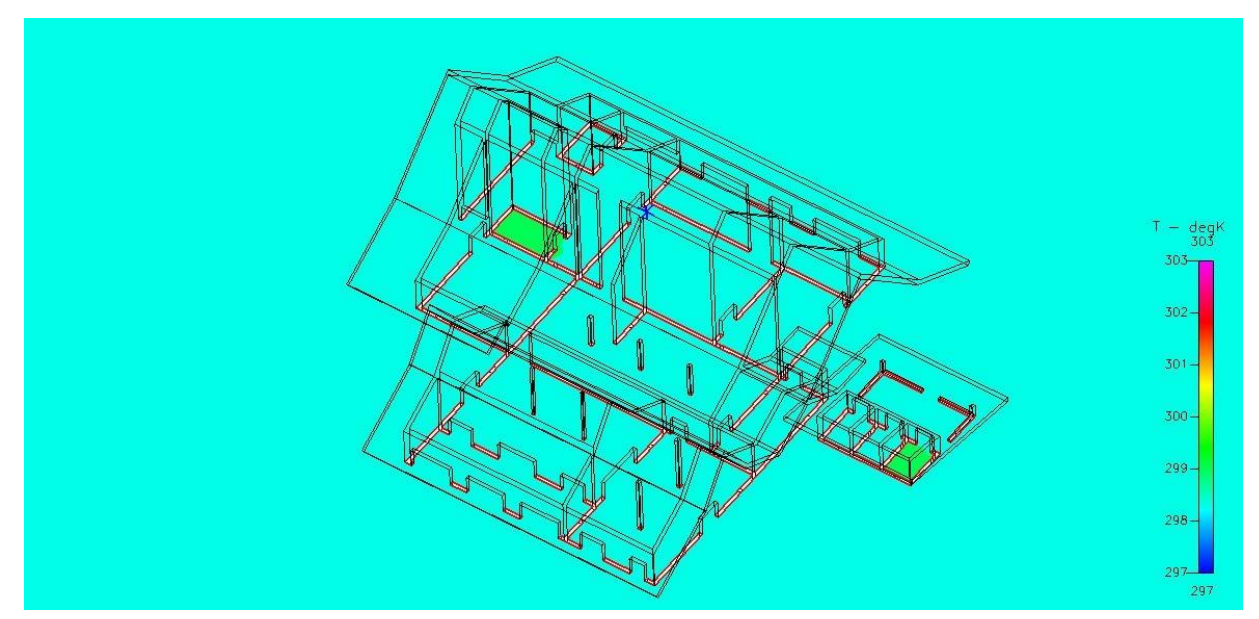

Figure 4. simulation of temperature on the traditional houses on the coldest month (Source: Author, 2011) 


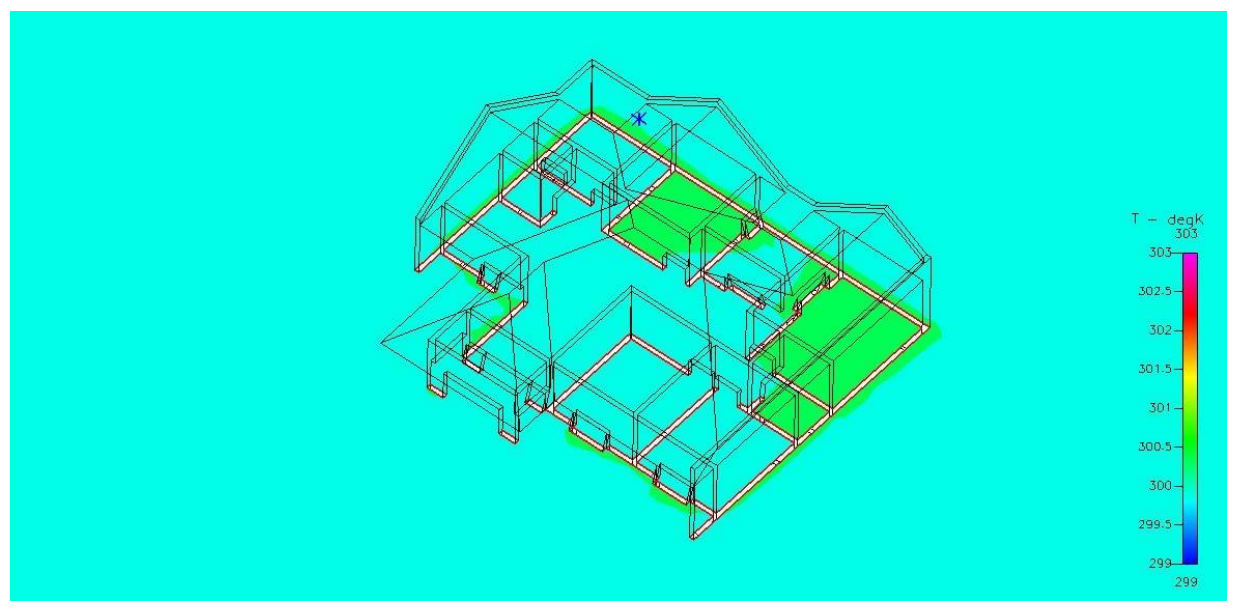

Figure 5. simulated temperature in contemporary homes in the hottest month (Source: Author, 2011)

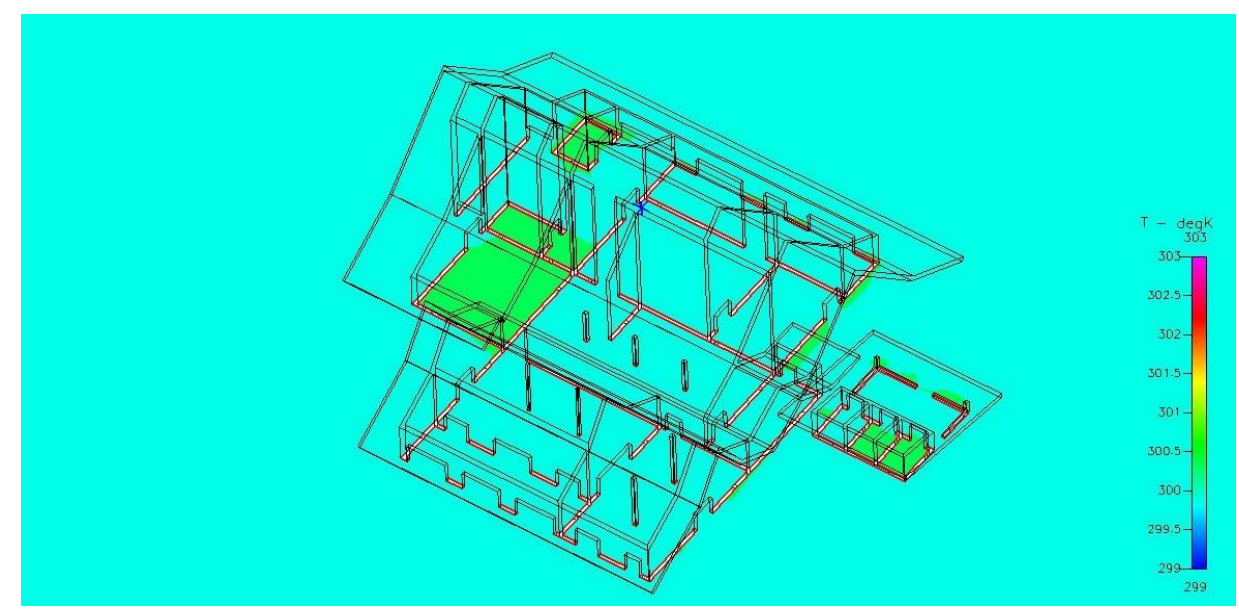

Figure 6. simulated temperatures in the traditional home at the hottest temperature (Source: Author, 2011)

Navy 0-0.5 m / s

Blue $0.5-1 \mathrm{~m} / \mathrm{s}$

Light green $1-1.5 \mathrm{~m} / \mathrm{s}$

Green $1.5-2 \mathrm{~m} / \mathrm{s}$

Wind speed seen in contemporary homes both in the hottest month (Fig. 7) and the coldest month (Fig.8) dominant $<1 \mathrm{~m} / \mathrm{s}$. Although in some sections appears to exist that have wind speeds $>1 \mathrm{~m} / \mathrm{s}$ but very minimal. Whereas in traditional houses either in the hottest month (Fig.9) and the coldest month (Fig.10) the dominant wind speed $>0.5 \mathrm{~m} / \mathrm{s}$ and spread to all parts of the house not only on the front associated with the front door only. 


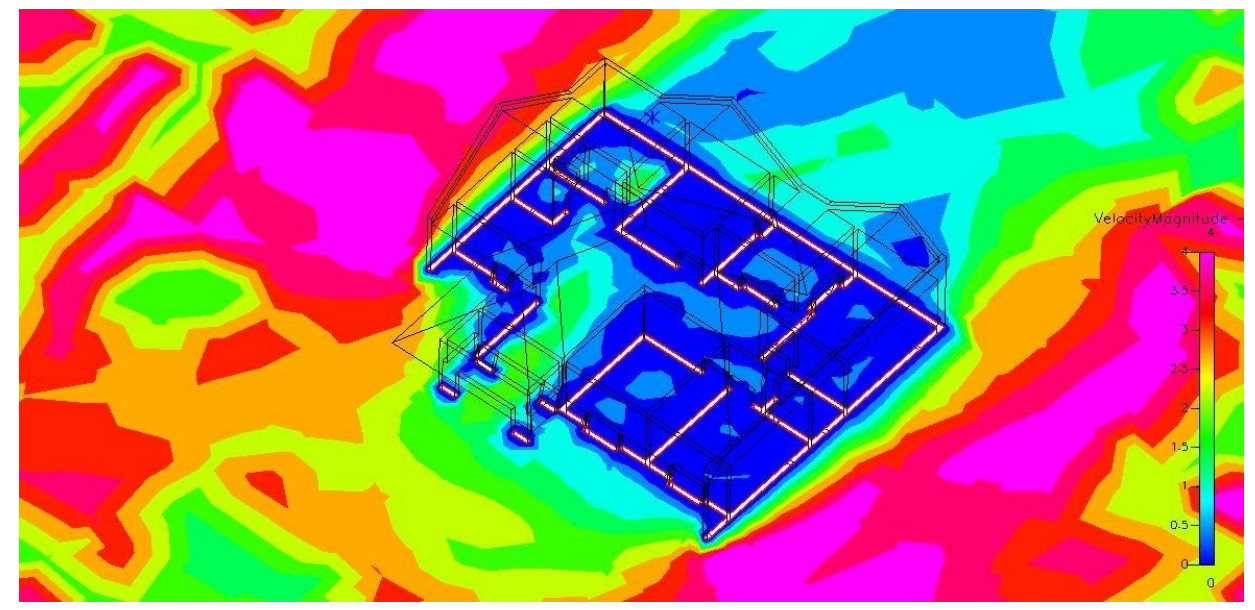

Figure 7. Wind speed simulation in contemporary home on the hottest temperature (Source: Author, 2011)

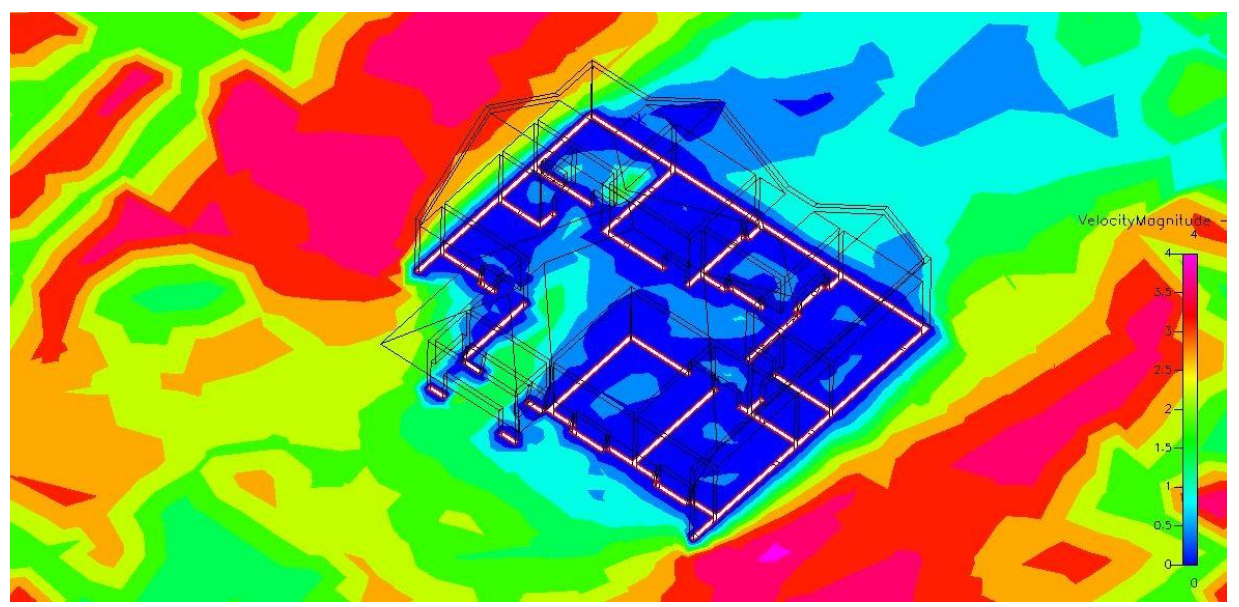

Figure 8. Wind speed simulation in contemporary home on the coldest temperature (Source: Author, 2011)

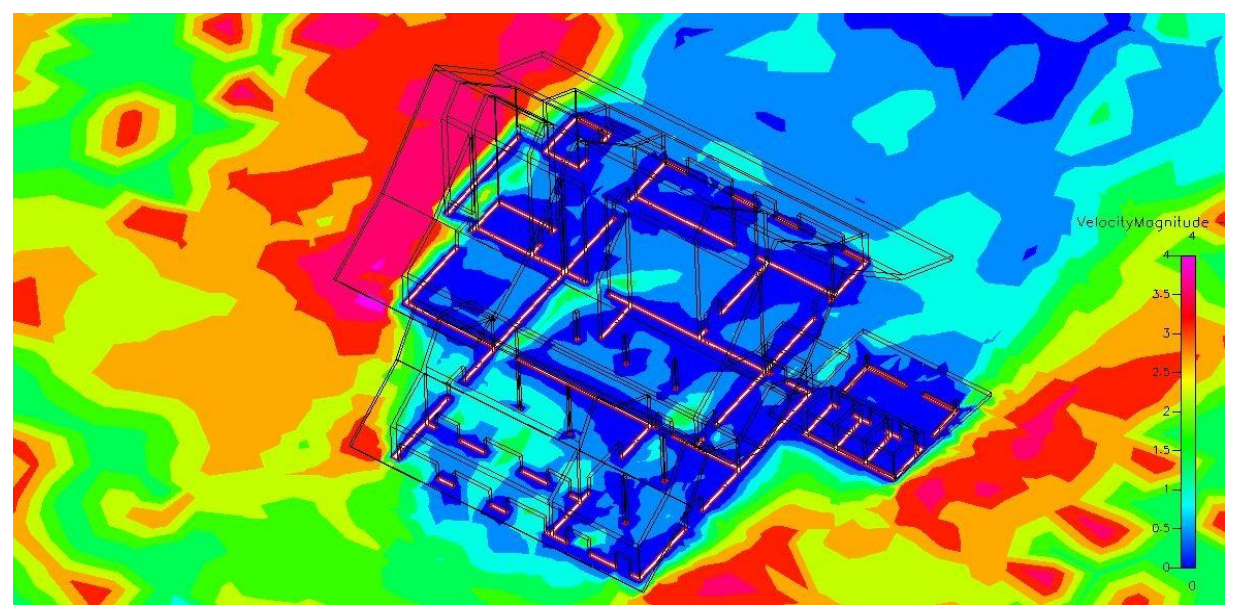

Figure 9. Wind speed simulation at the traditional houses on the coldest temperature (Source: Author, 2011) 


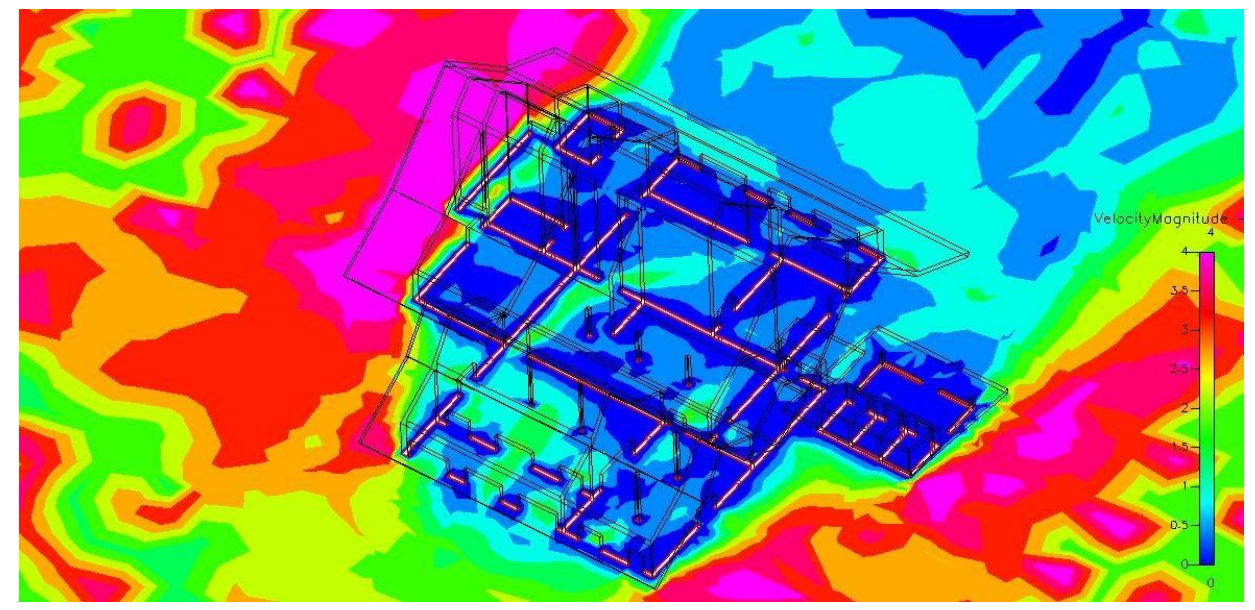

Figure 10. Wind speed simulation at the traditional houses on the coldest temperature (Source: Author, 2011)

The results obtained that the temperature generated at the simulation in a traditional house is closer to a comfortable temperature is $26.65{ }^{\circ} \mathrm{C}$ in the hottest month and $25.35{ }^{\circ} \mathrm{C}$ in the coldest months. Also shows the dominant wind speed at wind speeds $>0.5 \mathrm{~m} / \mathrm{s}$ and spread throughout the room. Although temperatures in the hottest month in the traditional home $>26{ }^{\circ} \mathrm{C}$ but due to a fairly uniform wind speed $0.5-1.5 \mathrm{~m} / \mathrm{s}$ which is sufficient to carry heat by convection and make the temperature more comfortable

\section{Conclusion}

Simulation is conducted with due respect to material that is half brick and one wall brick, floor tile all, the window glass and wood, all solid wood doors, clay tile roofs all. So it can be concluded That the use of materials on the wall and floor, window and door materials, roofing materials in traditional house proved to result in temperature and wind speed are comfort.

\section{References}

Koenigsberger, Ingersoll, Mayhew, Szokolay. 1978. Manual Of Tropical Housing And Building. America: Longman Inc.

PO Fanger. 1982. Thermal Comfort, Analisys And Applications In Environmetal Engineering. New York: Mc Graw Hill Company.

Szokolay, SV. 1987. Thermal Design of Buildings. Canberra RAIA: Education Devision.

Evans, M. 1980. Housing, Climate and Comfort. New York: John Wiley and Sons.

Egan, D. 1975. Concepts in Thermal Comfort. New Jersey: Prentice Hall Inc.

Idham, C., Aksugur, E. 2006. The Natural Acclimation of Javanese Vernacular House Typology. in Harmony in Culture and Nature, Inta Conference, Yogyakarta.

Iswati, T.Y. 2009. Kampung Dalem di Balik Kemegahan Kotagede. Surakarta: UNS Press.

Iswati, T.Y. 2011. Simulation of Thermal Performance Of Traditional Javanese House Compared With Contemporary House In Tropics Region In Yogyakarta. International Seminar on Climate Change Environment Insight for Climate Change Mitigation, Surakarta. 